\title{
ORGANIZATIONAL COMMUNICATIONS ON THE MEANING OF A CRITICAL APPROACH TO FEMINISTIC THEORY
}

\section{Oktri Permata Lani}

IAIN Batusangkar, Sumatera Barat, Indonesia

E-mail: oktripermatalani@iainbatusangkar.ac.id

*) Corresponding Author

\section{Muhammad Husni Shidqi}

IAIN Batusangkar, Sumatera Barat, Indonesia

E-mail:

muhammadhusnishidqi@iainbatusangkar.ac.id

\section{Ilham Havivi}

Universitas Andalas

E-mail: ilhamhavifi@soc.unand.ac.id

\section{Miftahurrahmi Fitri}

Politeknik Aisyah

E-mail: miftahurrahmifitri@gmail.com

\begin{abstract}
From the point of view of communication, there are many things that can be seen and studied. Especially in daily life, the point of view of communication is examined more deeply by using critical theory regarding the continuity of communication activities themselves. This theory relates to various related indicators, including language, organizational structure, interpersonal relations, and media. The organizational structure in the study involves the form of organizational communication, organizational culture and even the form of leadership communication in accordance with the structure formed. Communication itself according to a critical perspective is a result of the pressure (tension) between individual creativity in providing a framework for messages and social constraints. In both governmental and non-governmental organizations, they can build equal partnerships in each unit. It means every male and female worker or person should have the same opportunity to become top leaders in the unit where he or she works. Of course, if this is realized, it will build gender equality in the world of work. However, this cannot go smoothly as it is. The reality is there is still an imbalance of leaders in the unit sectors, both in government and non-government. Besides, violence against women is still happening today. Of course, this shows inequality and the low quality of life and the role of women. The research method used is qualitative in a literature review approach
\end{abstract}

Keywords: Organizational Communication, Feminist Critical Theory, Gender 


\section{INTRODUCTION}

In the critical theory approach, communication and other interrelated elements are usually inseparable. It can be emphasized that a critical theory of communication, whether viewed from an economic or political perspective, needs to involve a critique of society as a whole. Critical communication theory itself relates to various related elements, namely language, organizational structure, interpersonal relations and studies of the media

According to the critical perspective, communication is the result of various pressures (tensions) between individual creativity in producing messages and social barriers to creativity itself. In everyday life, gender issues are still found, which can be seen in the gender gap between men and women. It is undeniable, until now this phenomenon is still emerging.

This issue can be studied more deeply using a feminist critical theory approach. The issue of gender, for example, has become a separate approach that is influenced by feminist critical theory. Especially in recent weeks, gender gaps in several development fields have become a major topic, considering the international commitment to gender equality and justice is a common goal globally.

In the development of the millennial era, one goal is to balance the equal partnership of men and women with efforts to improve justice. As well as gender equality in every development sector. However, the problem of gender inequality can be illustrated by the low quality of life and the role of women. We can see this by the high level of violence against women. In addition, in the organizational structure of both government and nongovernment, the top leadership is still mostly held by men.

Nationally, the government issued a policy to address the gender gap that occurred, namely Presidential Instruction No. 9 of 2000 concerning Gender Mainstreaming in National Development. Gender equity is a strategy to realize equality and provide a form of gender justice in the development process.

In development, paying attention to gender equality and justice is one of the requirements to achieve development outcomes that bring benefits to both men and women. Policies in the millennial era regarding gender balance and equity still require a gradual and long process. The jam also still faces several challenges in the future. The biggest challenge is that the strong patriarchal culture is the cause of gender inequality which ultimately causes an unequal gender position in which women are victims.

In the initial observation, researchers obtained data in 2010 from the Ministry of PAN \& RB stating that the number of Civil Servants (PNS) was 4,598,100 people, consisting of $46.48 \%$ women and $53.52 \%$ men with a composition of female representation: Echelon I as much as 9\%, Echelon II as much as $7 \%$, Echelon III as much as $16 \%$ and Echelon IV as much as $25 \%$. The data shows that the higher the position, the lower the position of women. In addition, this data can also show gender inequalities that occur, not only in social life, but also in government organizations. The formation of structural officials at both the central and regional levels is still dominated by mostly men.

It is not excluded in the scope of the University, such as IAIN Batusangkar. IAIN Batusangkar has the following organizational 
structure: one rector, vice chancellor I, vice rector II and vice chancellor III. In addition, IAIN Batusangkar also has other leaders in four faculties, each consisting of the Dean of FTIK, Dean of Sharia, Dean of FEBI and Dean of FUAD. And has a postgraduate unit leader. The organizational structure at IAIN Batusangkar is generally led by men, only the Postgraduate Director of IAIN Batusangkar is female. From this, it is undeniable that the dominant organizational structure in the field of government is men. IAIN Batusangkar is only one example of an organization that is seen in the organizational structure of men. It is possible that other places or other universities also have the same organizational structure as IAIN Batusangkar. In connection with this, the author is armed with the book Organizational Communication (approaches and processes) by Katherine Miller and several books as well as supporting data trying to examine and focus on "Organizational Communication on the Meaning of a Critical Approach to Feminist Theory".

\section{METHOD}

This research is a qualitative research that is library research that uses books and other literatures as the main object (Hadi, 1995: 3). The type of research used is qualitative, namely research that produces information in the form of notes and descriptive data contained in the text under study (Mantra, 2008: 30).

\section{RESULTS AND DISCUSSION}

\section{Understanding Communication}

Humans as social beings cannot live alone, therefore they always need other people. To establish relationships with other people, humans need to communicate. Communication has an important role in achieving organizational goals. Through communication within an organization, the interaction between superiors and subordinates will be clearly visible in every delivery of messages or information that occurs in the organization.

A definition made by a group of communication scholars who specialize in the study of communication between humans (human communication) quoted by Cangara in the book Introduction to Communication Studies (2010:18) makes the definition that:

"Communication is a transaction, a symbolic process that requires people to regulate their environment by (1) building relationships between human beings (2) through the exchange of information (3) to strengthen the attitudes and behavior of others (4) and trying to change attitudes and behavior. do it"

Communication is a process where two or more people form or exchange information with each other, which in turn will arrive at a deep mutual understanding (Cangara, 2010: 18).

Communication can take place well if there is mutual understanding between the sender and recipient of the message, so that there is an understanding of an idea or idea. Through a good understanding, the purpose of communication to provide a stimulus for attitude change will be easily achieved. The communicant will receive the message conveyed by the communicator in accordance with the purpose of the communication itself.

Based on the description above, it can be concluded that communication is a human statement in the form of messages conveyed by the communicator to the communicant. A leader has a very important role in establishing 
communication with his employees. Effective communication within the organization is very important for achieving company goals, besides that effective communication is also one of the factors that support success in an organization.

\section{Communication Process}

Communication is essentially the process of delivering messages from the communicator to the communicant. The communication process that occurs in the company where the research is carried out is the communication process that occurs between leaders and employees. The communication process can be viewed from two perspectives, namely:

a. Communication Process in Psychological Perspective

1. The communication process that occurs in the communicator and the communicant.

2. When a communicator intends to convey a message to the communicant, then there is a process in him. The process of packaging or wrapping thoughts in language that the communicator does in the language of communication is called "encoding". The encoding result in the form of a message is then sent to the communicant.

3. Now it is the communicant's turn to be involved in the process of intrapersonal communication. The process in the communicant is called "decoding" by opening the package of the message he received from the communicator. If the communicant understands the content of the communicator's message, then communication occurs.

b. Communication Process in Mechanistic Perspective

This process occurs when the communicator passes the message in writing or verbally until it is captured by the communicant. The capture of this mechanistic perspective, where the message from the communicator to the communicant is carried out using the five senses. This process is complex or complicated because it is situational, depending on the situation when the communication takes place (Effendy, 2010: 31-33).

For this reason, an organization or company must pay attention to the communication process from a psychological and mechanistic perspective. The situation during the communication process between leaders and employees affects the effectiveness of the communication.

The elements in the communication process according to Philip Kotler are:

a) Sender is a communicator who conveys a message to or a number of people.

b) Encoding is the process of transferring thoughts into symbols.

c) Message is a message which is a set of meaningful symbols that are conveyed to the communicator.

d) Media is a communication channel where messages are passed from the communicator to the communicant.

e) Decoding is the process by which the communicant assigns meaning to the symbol conveyed by the communicator to him.

f) Receiver is the communicant who receives messages from the communicator.

g) Response is a response, a set of reactions from the communicant after being hit by a message.

h) Feedback is feedback, the response of the communicant when a message is conveyed from a communicator or a 
AGENDA : Analisis Gender dan Anak,Vol. 3 (2), 2021, (Desember)

ISSN Print: 2615-1502

ISSN Online: $\underline{2723-3278}$

Tersedia online di

message is conveyed to a communicator.

i) Noise is an unplanned disturbance that occurs in the communication process as a result of receiving a message by the communicant that is different from the message conveyed by the communicator to him

\section{Understanding Communication}

The definition of organizational communication according to Redding and Sanborn is as follows:

"Organizational communication is the sending and receiving of information within a complex organization. Included in this field are internal communication, human relations, management union relations, downward communication (superiors to subordinates), upward communication (subordinates to superiors), horizontal communication or communication from people of the same level or level in the organization, communication skills and speaking, listening, writing and communicating program evaluation" (Muhammad, 2001: 66).

Based on the understanding of communication according to Redding and Sanborn, the author will elaborate further on internal communication within the organization. As for what is meant by internal communication, namely communication that occurs between leaders and employees in a company.

"Internal communication is also referred to as the exchange of ideas between administrators and employees in a company or service complete with a distinctive structure (operations) and the horizontal and vertical exchange of ideas within the company or agency that causes work to take place (operations and management)" (Brennan in Effendy, 2010:112).

Internal communication in an organization is useful for aligning the goals of the organization, the goals of the leader and the goals of the employees. This can be done through formal and informal communication networks within the organization.

\section{Critical Approach}

a) According to Sendjaja (1994:392) all of them have the same three basic assumptions, namely: All of them use the basic principles of interpretive social science. Namely that critical scientists consider it necessary to understand people's experiences in context. In particular the critical approach aims to interpret and therefore understand how various social groups are constrained and oppressed.

b) This approach examines social conditions in an attempt to uncover structures that are often hidden. Most critical theories teach that knowledge is the power to understand how people are oppressed so that people can take action to change the power of oppression.

c) The critical approach consciously seeks to combine theory and action. The theories are clearly normative and act to achieve change in the various conditions that affect our lives.

Miller in his book Organizational Communication (2009), mentions that there 
AGENDA : Analisis Gender dan Anak,Vol. 3 (2), 2021, (Desember)

ISSN Print: 2615-1502

ISSN Online: $\underline{2723-3278}$

Tersedia online di

are 3 (three) issues that are commonly studied in this critical approach, including:

a) The social structure has brought a power imbalance. The point is that a structure that is not credible will create a social gap, between superiors and subordinates creating a large enough gulf. Superiors tend to have absolute power.

b) Power imbalance causes alienation/ oppression of certain classes. Uncontrolled power will make superiors act arbitrarily.

c) The role of critical theory is to uncover these imbalances.

According to Morgan in Miller (2009) sources of power in organizations that also affect communication in an organization are:

1) Formal authority

2) Control of resources, decisions, information, technology

3) Utilization of regulations, authority, and organizational structure.

4) Decision-making control

5) Control over knowledge and information

6) Control over various boundaries;

7) Ability to cope with uncertainty

8) Control over technology

9) Alliances, personal networks, and control over "informal organizations/groups"

10) Control over opposing organizations;

11) Symbolism of meaning management

12) Gender and gender relations management

13) Structural factors that determine the stages of action;

14) The power one has before

\section{Feminist Theory in Organizational Communication}

Women and men are different. Differences between women and men can be grouped into biological differences and differences as a result of socio-cultural construction. The biological differences between women and men are commonly referred to as sex (gender). Differences between women and men as a result of sociocultural construction are commonly referred to as gender.

Biological differences between women and men can be seen from the biological characteristics between the two, both primary characteristics (always present in certain sexes) and secondary characteristics (tends to exist in certain sexes but not always in certain sexes). exist in that gender).

Women and men have different roles, functions, responsibilities, attitudes and behaviors as a result of social and cultural construction. This is commonly known as gender. This difference is formed through a process of continuous habituation so that it is internalized in every person, every family, every community. 5 This socialization process is carried out through:

1) Families often divide roles between men and women traditionally, where women tend to be accustomed to doing domestic roles (housekeeping) and men are accustomed to playing public roles. Habituation of this role is carried out continuously from day to day, since a person is born to adulthood so that it eventually forms a gender ideology.

2) Society is used to labeling the division of roles between men and women as is usually done at the family level, so that when someone or a group of people 
perform roles other than the division it is considered unusual or strange

3) The state confirms the division of roles of women and men through the various regulations it produces.

4) Schools often transform genderbiased values through examples of teaching materials and learning processes in schools. For example, when it comes to sports, movement and group division must be distinguished between men and women. The sports movements of male students seem to be heavier, while the sports movements of female students seem lighter.

5) Workplace: the workplace often assigns roles to women and men differently as a result of socio-cultural construction. Men often get jobs that are considered to require ratio, speed of decision making or innovation. Meanwhile, women often get jobs that require precision and feelings, such as being a secretary, nurse, kindergarten/elementary school teacher. Not only that, in leading an organization, company or government agency and university, until now it is still dominated by men. There are still very few presentations of female leaders in this sphere.

6) The mass media often reinforces the notion of women and men through the news they make. Women are often shown to be attractive because their physical appearance is beautiful, sexy, while men are often shown to be attractive because of their achievements.

In the organizational approach, a finding appears that the most valued commodities are male-type characters such as aggressiveness and competitiveness. On the other hand, female-type characters such as intuition, emotion, empathy, harmony, and cooperation seem to be underestimated in organizational life. Feminist experts say that the concepts used in understanding organizational life, (such as rationality and hierarchy) tend to be male biased (Mumby and Putnam, 1992) and that the language structure in organizations is also patriarchal (see also Penelope, 1990). To make it clearer the various points of view and ideas of feminist activists, the following table is presented as follows:

\begin{tabular}{|c|l|l|}
\hline No. & \multicolumn{1}{|c|}{$\begin{array}{c}\text { Sudut } \\
\text { Pandang }\end{array}$} & $\begin{array}{l}\text { Gagasan feminists } \\
\text { feminists }\end{array}$ \\
\hline 1 & Liberal & $\begin{array}{l}\text { Liberal the } \\
\text { believe that } \\
\text { abolition of women's } \\
\text { subordination must } \\
\text { originate from the } \\
\text { system, and women } \\
\text { should strive for a fair } \\
\text { role in controlling the } \\
\text { institutions that are } \\
\text { ruled by men. Other } \\
\text { feminists who disagree } \\
\text { with this approach say } \\
\text { that this approach will } \\
\text { only further strengthen } \\
\text { the patriarchal climate } \\
\text { in society. }\end{array}$ \\
\hline 2 & Radical \\
feminists & $\begin{array}{l}\text { Radical feminists } \\
\text { believe that women's } \\
\text { emancipation will only } \\
\text { be realized through the } \\
\text { destruction of male- }\end{array}$ \\
\hline
\end{tabular}




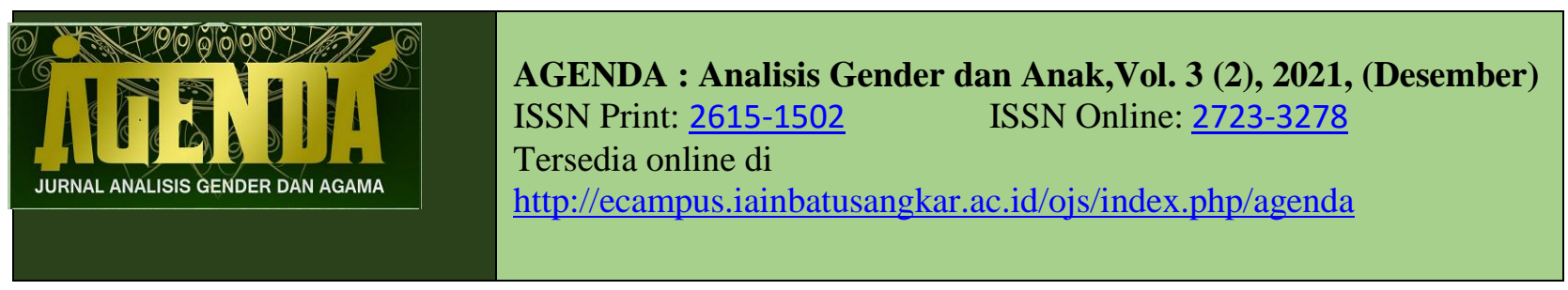

\begin{tabular}{|l|l|l|}
\hline & $\begin{array}{l}\text { dominated institutions, } \\
\text { or through the total } \\
\text { separation of women } \\
\text { from such institutions. } \\
\text { While other feminists } \\
\text { propose for more } \\
\text { symbolic actions. }\end{array}$ \\
\hline 3 & $\begin{array}{l}\text { Standpoint } \\
\text { feminists }\end{array}$ & $\begin{array}{l}\text { Standpoint feminists } \\
\text { work to strengthen } \\
\text { opportunities for } \\
\text { marginalized voices to } \\
\text { be heard in community } \\
\text { dialogue. In this theory, } \\
\text { Harding and Wood } \\
\text { suggest that one of the } \\
\text { best ways to find out } \\
\text { how our world is doing } \\
\text { is to start our } \\
\text { investigation from the } \\
\text { standpoint of women } \\
\text { and other marginalized } \\
\text { groups. }\end{array}$ \\
\hline 4 & $\begin{array}{l}\text { Postmodern feminists } \\
\text { attempt to } \\
\text { "deconstruct" the male- } \\
\text { dominated system to } \\
\text { bring out a female } \\
\text { perspective }\end{array}$ \\
feminists & $\begin{array}{l}\text { Postmodern } \\
\text { form }\end{array}$ \\
\hline
\end{tabular}


Reference source: Organizational Communication (approaches and processes) by Katherine Miller.

\section{CONCLUSION}

Especially nowadays, the issue of gender which causes gender gaps in several development fields is the main topic, considering the international commitment to gender equality and justice is a common goal globally. Gender issues are so full of organizational life. Many organizational communication experts adopt feminist theory as the basis of their work. Organizations in both traditional and bureaucratic forms are very patriarchal. They further reveal that women have a distinctive way of looking at the world and create meanings through interactions. Feminist experts believe that women in organizations can be oppressed/marginalized in organizational life due to the dynamics of gender relations formed by a patriarchal organizational structure. critical perspective is a result of the pressure (tension) between individual creativity in providing a framework for the message and social constraints on creativity. The issue of gender, for example, has become a separate approach that is influenced by feminist critical theory.

Liberal feminists believe that the abolition of women's subordination must originate from the system, and women should strive for a fair role in controlling the institutions that are ruled by men. Radical feminists rely on the view that oppression of women occurs as a result of a patriarchal system. The female body is the main object of oppression by male power. Therefore, radical feminism takes issue with, among others, the body and reproductive rights, sexuality (including lesbianism), sexism, power relations between women and men, and the privatepublic dichotomy. "The personal is political" has become a new idea that is able to reach women's problems to the private sphere, issues that are considered the most taboo to be brought to the surface. A standpoint is a place where we perceive the world around us. Whatever the vantage point, the location tends to focus our attention on some features in the landscape and social by obscuring other features. Standpoint has the same meaning as viewpoint, perspective, outlook, or position. Note that these terms are used in specific places and times, but they all relate to behavior and values. Our standpoints affect our worldview. Postmodern ideas according to their opinion - are ideas that are anti-absolute and anti-authority, the failure of modernity and the different separation of each social phenomenon because of its opposition to the universalization of scientific and historical knowledge.

\section{REFERENCES}

Effendy, Onong. 2010. Communication Science theory and practice. PT. Youth Rosdakarya Bandung.

Spectrum. CV. Mandar Forward
Bandung.

\section{Communication}

Dynamics. Bandung alumni.

Hafied, Cangara. 2010. Introduction to Communication Studies Second Edition. Youth Rosdakarya Bandung. 
Katherine Miller.2012 (Texas A \& M University), Organizational Communication (approaches and processes), Sixth Edition, Wadsworth Cengage Learning.

Muhammad, 2001. Organizational Communication, its form and function. Youth Rosdakarya Bandung.

Mulyadi, Deddy. 2008. "CompetencyBased HR Development Through Systemic Education and Training Management as a New Paradigm in Organization and Management" in Apparatus Training Journal, Vol.4, No.1, pp.1-12.

Press Release KPPPA Gender Mainstreaming Encourages the Improvement of Competent and Professional State Apparatus 20 December 2012, source : http://menegpp.go.id/V2/index.php/c omponent/content/article/10gender/465press-release-pug pushing-a-competent-andprofessional-state apparatus

Sendjaja, Sasa Djuarsa. 1993. Communication Theory. Jakarta: Open University. 